\title{
Brazil's Cattle Sector Played Large Role in Fires During 2020 Moratorium
}

OPEN ACCESS

Edited by:

Kerry Turner,

University of East Anglia,

United Kingdom

Reviewed by:

Peichen Gong,

Swedish University of Agricultural

Sciences, Sweden

Thiago Morello,

Federal University of $A B C$, Brazi

Ilda Dreoni,

University of Southampton,

United Kingdom

*Correspondence:

lan H. Schelly

Ischelly@wisc.edu

Specialty section:

This article was submitted to

People and Forests,

a section of the journal

Frontiers in Forests and Global

Change

Received: 18 August 2021

Accepted: 28 October 2021

Published: 25 November 2021

Citation:

Schelly IH, Rausch LL and Gibbs HK (2021) Brazil's Cattle Sector Played Large Role in Fires During 2020 Moratorium

Front. For. Glob. Change 4:760853. doi: $10.3389 /$ ffgc. 2021.760853

\section{Ian H. Schelly ${ }^{1 *}$, Lisa L. Rausch ${ }^{1}$ and Holly K. Gibbs ${ }^{1,2}$}

${ }^{1}$ Center for Sustainability and the Global Environment, Nelson Institute for Environmental Studies, University of Wisconsin-Madison, Madison, WI, United States, ${ }^{2}$ Department of Geography, University of Wisconsin-Madison, Madison, WI, United States

In response to global concern about recent fires, Brazil placed a 120-day moratorium on burning in the Amazon in 2020. We assessed how the cattle sector was linked to these fires by estimating the number of cattle properties involved with fires despite the moratorium, and their roles in cattle supply chains. We examined the land cover prior to the fire to identify instances of fires associated with recent deforestation. Our results show that the cattle sector contributed disproportionately to the fires in 2020, in terms of both the number of properties involved and the area burned. Improvements in both supply chain policies and overall environmental governance in the Amazon are likely needed to avoid recurrences of the catastrophic scale of fires during the 2020 season.

Keywords: Brazil, cattle, fire, supply chain policy, Amazon

\section{INTRODUCTION}

Fires are a critical environmental and social issue in the Amazon and are closely linked to cattle ranching (Chain Reaction Research, 2020). They are commonly used in the Amazon as a lowcost management tool in already established pastures or fields to control pests or fertilize soils (Cammelli, 2013; Carmenta, 2013; Cammelli et al., 2020). Fires like this are an important part of small-scale agriculture and traditional livelihoods that have depended on the use of fires for hundreds of years (Fraser et al., 2012; Peña-Venegas et al., 2017), but they also occur on commercial cattle producing properties with direct connections to major slaughterhouses. These fires may be the final step of the deforestation process, in which they are set after trees have been felled and left to dry to clear the way for new pasture or agricultural fields. Cases where deforestation precedes burning should result in the exclusion of properties as direct suppliers to slaughterhouses that have signed zero deforestation agreements (Gibbs et al., 2016; Skidmore et al., 2020). However, burning pastures is not prohibited by zero-deforestation agreements although these fires carry a substantial risk of escaping into forests or onto neighboring properties (Cano-Crespo et al., 2015; Setzer et al., 2016). Furthermore, the use of fire to manage fields and pastures may perpetuate low yields, environmental degradation, and trap farmers into a cycle of lower profits and risky agricultural fire use over the long term (Cammelli et al., 2020). Additional negative impacts of widespread fires include loss of biodiversity and increased carbon emissions (Barlow et al., 2016; Aragão et al., 2018).

The 2020 fire season was the worst in a decade and followed on the heels of similarly elevated rates of burning in the 2019 season, capturing the world's attention and generating extensive media coverage (CNN, 2020; Greenpeace, 2020; The Guardian, 2020). In response to the public outcry, the Brazilian government instituted a 120-day moratorium on burning in the Amazon that ran from July 16, 2020 through November 13, 2020 (Brazil, 2020). Here we analyze the actors involved with burning during the portion of the 2020 fire season covered by the moratorium and assess the role of the cattle sector in these fires. Many of these fires were assumed to be associated with land clearing, 
ranching, and agricultural activities, but the prevalence and scale of involvement of different actors has not been fully explored.

We combine novel research on the location of cattle properties and the structure of cattle supply chains with daily fire detections to assess the distribution of fires across properties in the Amazon. Our study focuses on fires that occurred in the period during the moratorium on burning and covers the three most important ranching states in the Amazon - Mato Grosso, Pará, and Rondônia. We used property maps from CAR, INCRA, and TerraLegal in combination with the $201930 \mathrm{~m}$ pasture data produced by MapBiomas from their version 5.0 landcover map (Terra Legal, 2015; INCRA, 2020; MapBiomas Project, 2020; SiCAR, 2020). We defined cattle properties as those with > 25 ha of pasture area. Our approach identified 54\% of all properties as cattle properties, which is similar to the estimate from IBGE (2017) that identifies 52\% of rural properties in our study region as being involved in livestock production. We report both the area burned and the count of properties involved in fires during the moratorium to better understand the number and type of actors involved or affected. The number of cattle properties involved is particularly relevant to Brazil's Zero Deforestation Cattle Agreements, the G4 and the TAC, which assign sanctions at the property level for deforestation and other forms of illegality. Fires are not specifically prohibited by the agreements but create reputational risk for slaughterhouses and thereby have begun to generate significant concern within the cattle sector and among policymakers (Mighty Earth, 2019; Chain Reaction Research, 2020).

To determine the locations of the fires, we overlaid VIIRS $375 \mathrm{~m}$ fire detection data from the Global Fire Emissions Database (GFED) with the map of property boundaries. Only fire detections classified as 'high confidence' were used. We considered a property to have a fire when a detection point fell within the property boundaries, regardless of the land cover of the fire that occurred. In our subsequent analysis of the land cover that preceded the fire, we overlaid the fires data with the $30 \mathrm{~m}$ 2019 PRODES land cover map and DETER deforestation alerts to classify the land cover type (i.e., forest, recently deforested, pre-2017 deforested, or non-forest) that the fire was located on (Global Fire Emissions Database [GFED], 2020; TerraBrasilis, 2020; Figure 1). Specifically, we selected the land cover type of the pixels that the fire points or polygons were located on. We considered a fire to have occurred on recent deforestation when that deforestation occurred in 2017 up to the start of the fire moratorium (i.e., up to 3 years prior to the fire).

To further connect properties to the cattle sector and assess their role in the supply chain, we linked our property maps with the official Animal Transit Guide (Portuguese language acronym, GTA) transactions from January 2014 through June 2020, which is the most recent data that is publicly available. The GTA documents all cattle transactions between properties and to slaughterhouses, but not all properties with pasture are included in the GTA because, for example, some ranchers own several properties but register sales from only one. We defined direct suppliers as those properties who sold to a slaughterhouse after January 2016, and indirect suppliers as those properties selling to a direct supplier in the 2 years prior to a transaction for slaughter, which could be as far back as 2014. We assessed whether these properties appearing in the GTA had fires during the moratorium on burning as described above and characterized the role of the properties with fires in the supply chain in the years prior to the moratorium. We could not track the supply chain role or transactions after the moratorium due to lack of publicly available GTA data during this time. We note that properties that burned during the moratorium and the prevalence of fires on areas of recent deforestation or other land covers may not be typical of non-moratorium periods.

\section{LARGE-SCALE CATTLE PROPERTIES LINKED TO MOST FIRES}

Fires occurred disproportionately on cattle properties in terms of both area burned and number of properties involved. Of the total burned area that occurred on properties in our study region, $87 \%$ (3.2 Mha) was located on cattle properties (Figure 2). The role of cattle properties in the fires was also evident when we considered numbers of properties involved, regardless of the scale of the fire. Cattle properties accounted for $68 \%$ of properties with fires on any type of landcover $(31,581$ out of 46,740$)$ though they only represented $54 \%$ of properties in our study area $(244,624$ out of 454,866) (Figure 3).

Although most of the area burned on private properties occurred in areas without recent deforestation $(\sim 85 \% ; 3,085,641$ ha), such as on pastures or other land covers, cattle properties bore most of the deforestation-related burning (Figure 2). Nearly all $(94 \% ; 518,032 \mathrm{ha})$ of the recently deforested burned areas within private property boundaries fell on cattle properties, which amounted to $16.4 \%$ of the total burned area on cattle properties (Figure 2). Only $7.4 \%$ (35,883 ha) of the burned area on noncattle properties fell on deforested areas (Figure 2). Over three quarters $(77 \%)$ of properties with fires linked to deforestation were cattle properties (7,352 out of 9,549) (Figure 3).

Fires were concentrated on larger properties and most large properties with fires were cattle properties. For example, very large properties (those $>1,000 \mathrm{ha}$ ) made up only $5 \%$ of the total properties in our study but represented $16 \%$ of the properties with fires $(7,546$ out of 46,760$)$ and $21 \%$ of the properties with fires on areas with recent deforestation $(2,032$ out of 9,549) (Table 1). Cattle properties accounted for $77 \%$ of these very large properties, $89 \%$ of the very large properties with fires, and $94 \%$ of the very large properties with recent deforestation fires (Table 1). Cattle properties were similarly dominant among properties $<100$ and 400-999 ha in size in terms of both fires in general and fires on deforested areas, only among properties 100-399 ha did fires fall in similar proportions on non-cattle properties as on cattle properties (Table 1). The average cattle property in our sample was 440 ha ( $\pm 4,557 \mathrm{ha})$ and the average non-cattle property was 131 ha $( \pm 1,000$ ha). Note that some fires on properties we have classified as cattle properties in our study could have been set for other purposes, such as creation of swiddens for agriculture or other traditional land management strategies, which are most frequently used by smallholders (properties smaller than $\sim 400$ ha in the Brazilian Amazon) (Carmenta et al., 2013). 


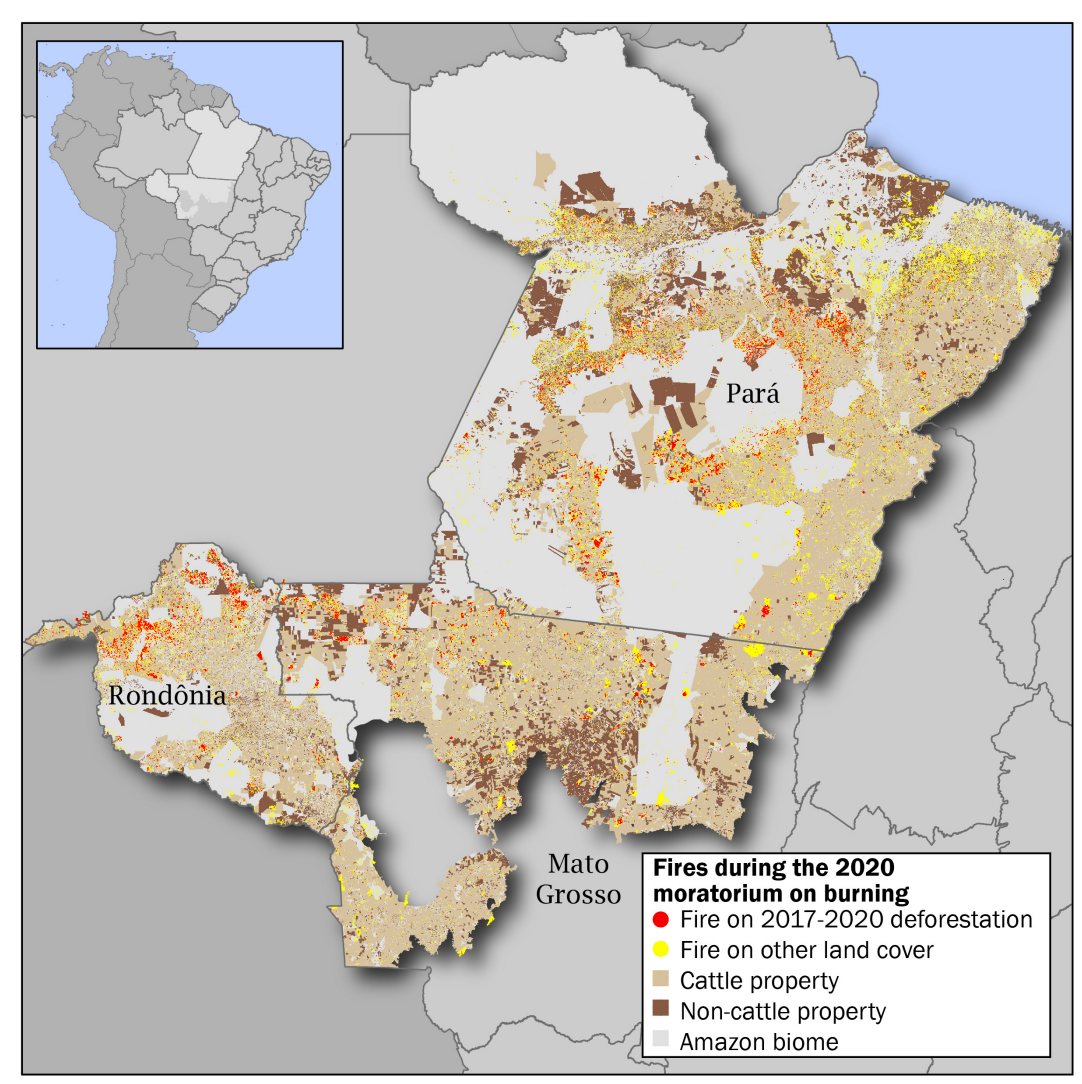

FIGURE 1 | Properties and burned area during the moratorium and type of land cover burned.

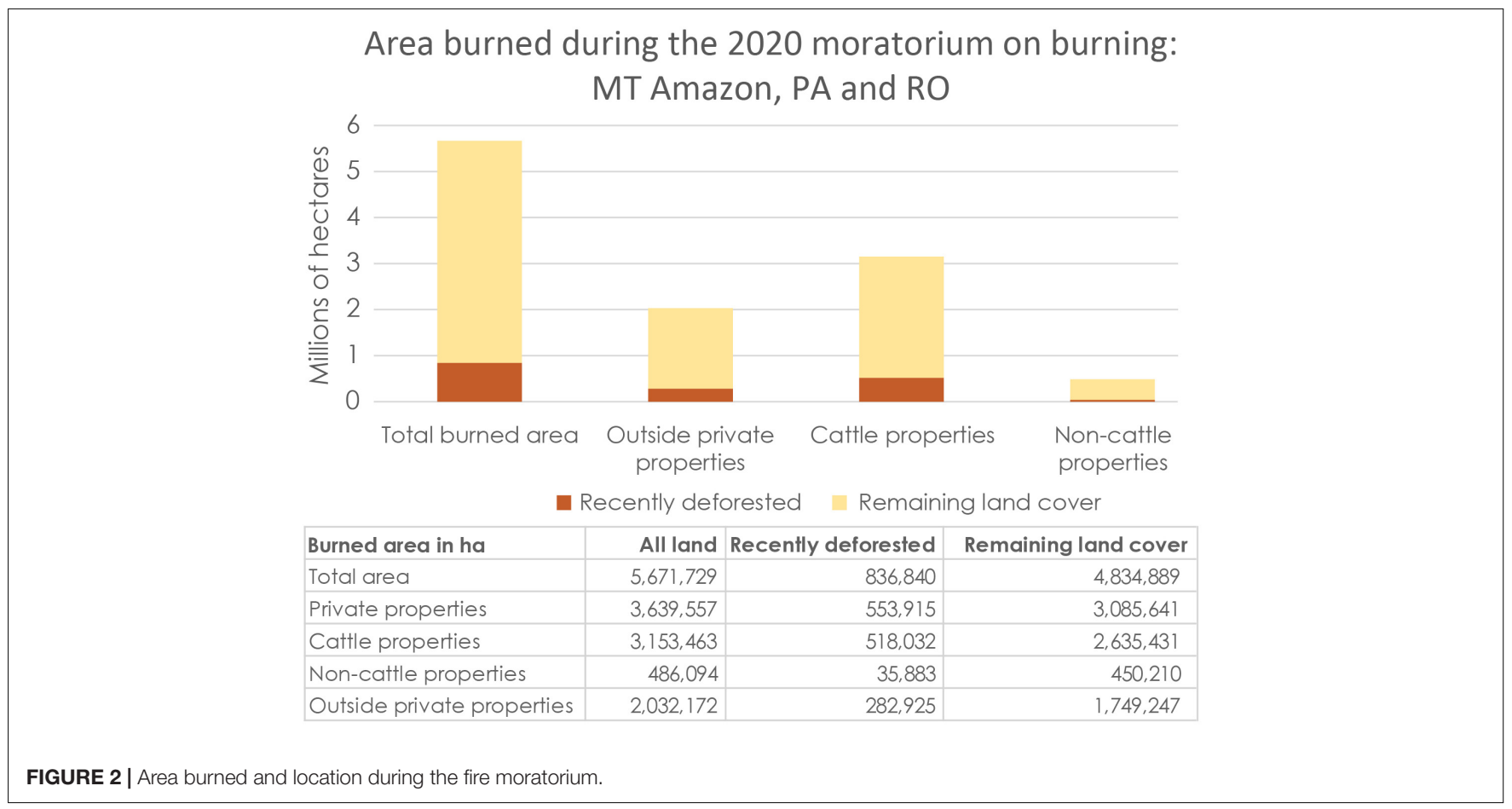




\section{Distribution of fires by property type}

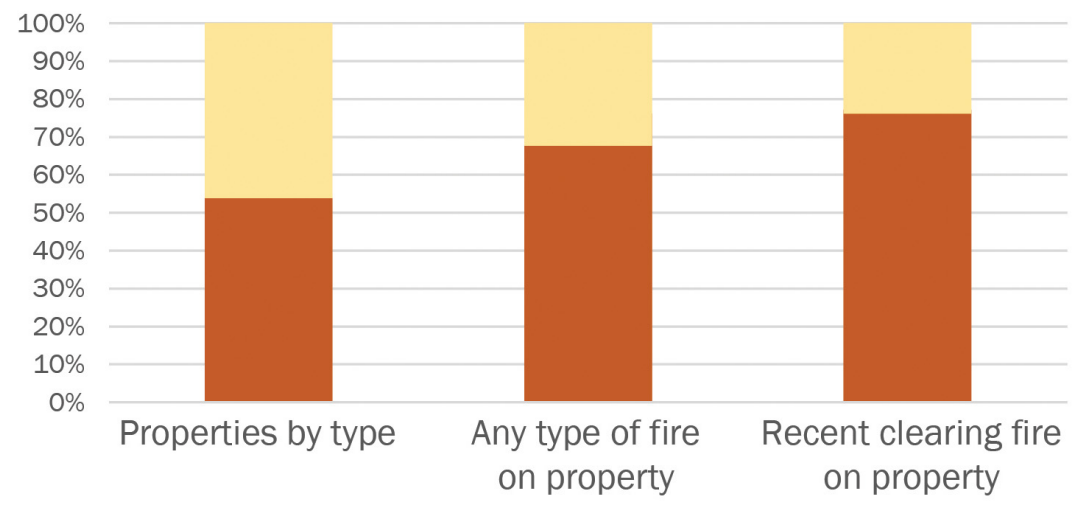

Cattle properties Non-cattle properties

FIGURE 3 | Distribution of properties and fires by type.

TABLE 1 | Proportion of cattle vs. non-cattle properties by size.

\begin{tabular}{|c|c|c|c|c|c|c|}
\hline & & Total & $<100$ ha & $100-400$ ha & $400-1000$ ha & $>1000$ ha \\
\hline \multirow[t]{2}{*}{ All properties } & Cattle properties & $53.8 \%(244,624)$ & $42.5 \%(133,809)$ & $79.7 \%(75,168)$ & $79.7 \%(17,931)$ & $76.6 \%(17,716)$ \\
\hline & Non-cattle props & $46.2 \%(210,242)$ & $57.5 \%(181,103)$ & $20.3 \%(19,162)$ & $20.3 \%(4,563)$ & $23.4 \%(5,414)$ \\
\hline \multirow[t]{3}{*}{ Properties with fireson recent deforestation } & Cattle properties & $85.1 \%(2,506)$ & $58.8 \%(265)$ & $83.2 \%(636)$ & $90.4 \%(498)$ & $94.0 \%(1,107)$ \\
\hline & Non-cattle props & $14.9 \%(438)$ & $41.2 \%(186)$ & $16.8 \%(128)$ & $9.6 \%(53)$ & $6.0 \%(71)$ \\
\hline & & Total & $<100$ ha & $100-400$ ha & 400-1,000 ha & $(>1,000$ ha \\
\hline \multirow[t]{2}{*}{ All properties } & Cattle properties & $53.8 \%(244,624)$ & $42.5 \%(133,809)$ & $79.7 \%(75,168)$ & $79.7 \%(17,931)$ & $76.6 \%(17,716)$ \\
\hline & Non-cattle props & $46.2 \%(210,242)$ & $57.5 \%(181,103)$ & $20.3 \%(19,162)$ & $20.3 \%(4,563)$ & $23.4 \%(5,414)$ \\
\hline \multirow[t]{2}{*}{ Properties with fires } & Cattle properties & $67.6 \%(31,581)$ & $47.5 \%(9,864)$ & $79.1 \%(10,721)$ & $88.5 \%(4,298)$ & $88.8 \%(6,698)$ \\
\hline & Non-cattle props & $32.4 \%(15,159)$ & $52.5 \%(10,913)$ & $20.9 \%(2,838)$ & $11.5 \%(560)$ & $11.2 \%(848)$ \\
\hline \multirow[t]{2}{*}{ Properties with fires on recent deforestation } & Cattle properties & $70.0 \%(7,352)$ & $56.2 \%(1,869)$ & $82.1 \%(2,425)$ & $92.2 \%(1,142)$ & $94.3 \%(1,916)$ \\
\hline & Non-cattle properties & $23.0 \%(2,197)$ & $43.8 \%(1,457)$ & $17.9 \%(527)$ & $7.8 \%(97)$ & $5.7 \%(116)$ \\
\hline
\end{tabular}

\section{PROPERTIES WITH FIRES LINKED TO MAJOR SLAUGHTERHOUSES}

Properties with fires were prominent in Brazil's commercial cattle supply chains. Over a third of the properties with fires $(37 \%$; 17,471 out of 46,740 total properties with fires) were participants in cattle supply chains formally documented in the GTA between 2014 and 2020, either as direct suppliers to slaughterhouses or as indirect suppliers that sold younger cattle to the direct suppliers. Over a quarter (26\%; 5.9 million) of heads sold for slaughter between 2016 and 2020 passed through properties with fires. Properties with deforestation-related fires appeared among GTA properties at a similar rate as those with fires overall $(33 \% ; 3,101$ out of 9,549 properties), though these properties produced only $1.9 \%$ of the cattle slaughtered in 2016-2020 (444,132 heads).

Most burned properties in the GTA could be linked to the major slaughterhouses that are part of the zero-deforestation agreements (79\%; 13,767 out of 17,471 total GTA properties with fires). We identified 5,186 properties with fires that directly supplied to zero-deforestation slaughterhouses in the 4 years prior, which represents $15 \%$ of the total number of direct suppliers to these slaughterhouses during the same time period. Just 721 of these properties burned an area with recent deforestation, which amounts to $14 \%$ of the direct suppliers with fires and $2 \%$ of the total number of direct suppliers to these slaughterhouses. An additional 8,581 properties with fires indirectly supplied zero-deforestation slaughterhouses by selling cattle to their direct suppliers; 1,551 of these indirect suppliers had a fire associated with deforestation.

Though our GTA data showing formal participation in cattle supply chains predates the period of the fire moratorium and our study period, many direct suppliers to major slaughterhouses have stable, ongoing relationships with these companies (Pereira et al., 2020). For most companies, the fires alone will not result in exclusion from the supply chain, because the zero-deforestation agreements do not prohibit burning. Indeed, only $18 \%$ of GTA properties with fires had deforestation-related fires $(3,101$ out of 17,471 GTA properties with any fire), highlighting the need for policies that specifically limit burning in cattle supply chains to reduce the role of the cattle sector in fires. Even those properties with deforestation preceding the fire, which should result in their exclusion as direct suppliers to many major slaughterhouses, can 
continue as indirect suppliers since current implementation of the agreements is limited to direct suppliers (Gibbs et al., 2016; Alix-Garcia and Gibbs, 2017; Skidmore et al., 2020).

\section{TWO-THIRDS OF BURNED AREA WAS LOCATED ON PRIVATE PROPERTIES}

In total, almost 5.7 Mha burned across our study area during the moratorium, with $15 \%$ of this area occurring on recently deforested land $(836,840$ ha) (Figures 1, 2). Most fires occurred on private properties, and over $10 \%(46,740)$ of properties in Mato Grosso, Pará and Rondônia had fires during the 2020 moratorium on burning, including both cattle properties and non-cattle properties, with 20\% $(9,549)$ of these properties experiencing fires on recently deforested areas. However, an extensive area outside of registered properties was also burned, highlighting the importance of strengthening governance that extends beyond formal supply chains and includes all agropastoral and deforestation frontiers. Registered property boundaries covered $50 \%$ of our study area but $36 \%$ of all burned area (2 Mha) and $34 \%$ of the burned area on recently deforested land $(282,295 \mathrm{ha})$ fell outside of these boundaries (Figure 2). Fires that occurred outside of registered properties may have occurred on unclaimed lands or on farms with informal land tenure or that have not yet been submitted to Brazil's Forestry or Settlement Agencies as private properties. Cattle production is a common activity in areas under informal or tenuous land claims, where enforcement of environmental policies is notoriously challenging (Araujo et al., 2009; Reydon et al., 2020).

\section{ACTIONABLE RECOMMENDATIONS}

Brazil's cattle sector has long been the subject of scrutiny for its role in Amazon deforestation (Mongabay, 2017). Domestic and international pressure contributed to the implementation by major slaughterhouses of zero-deforestation sourcing agreements that ban transactions with suppliers with deforestation on their properties (Mongabay, 2020). Now concerns about the scale and environmental consequences of widespread fires in the Amazon are increasingly posing reputational risks to many of the same slaughterhouses (Chain Reaction Research, 2020). This new public awareness and pressure could open the door to the inclusion of burning prohibitions in existing supply chain agreements or the implementation of new policies designed to ensure that properties with fires are excluded from supply chains (Global Canopy, 2021).

The zero-deforestation cattle agreements could serve as a useful model for reducing the incidence of fires since so many fires are linked to cattle production. Indeed, the cattle agreements have already reduced the number of direct suppliers to signatory slaughterhouses with deforestation and contributed to rapid rates of CAR registration (Gibbs et al., 2016; Skidmore et al., 2020), and have served as part of an overall improvement in propertylevel enforcement of environmental policies (Börner et al., 2015). However, not all slaughterhouses have signed the agreements, not all slaughterhouses monitor effectively (OECO, 2019; Global Witness, 2020), and the requirements in the agreements are not yet implemented for indirect suppliers (Walker et al., 2013; Gibbs et al., 2016; Skidmore et al., 2020; Zu Ermgassen et al., 2020), which creates ample opportunities for laundering and leakage and has at least partially washed out any overall reductions in deforestation from the agreements (Alix-Garcia and Gibbs, 2017). Fully implementing the current agreements across all slaughterhouses could help address these challenges and substantially reduce those fires related to deforestation by greatly limiting the economic options for the use of newly cleared areas and, thus, the potential payoffs from deforestation.

Additionally, because fires on pasture lands have the highest risk to escape the planned burn area and burn out of control into forested areas (Setzer et al., 2016), a permanent extension of significant restrictions on most large-scale burning in the Amazon, including for clearing pastures, could directly reduce the incidences of fires that may escape pastures and move into forests (Cano-Crespo et al., 2015). Fires can now be detected in real time with existing satellite monitoring technology (Global Fire Emissions Database [GFED], 2020), so slaughterhouses would also be well poised to exclude those properties with largescale fires if existing supply chain agreements were updated or new ones were implemented. For example, expanded legal restrictions on burning could also lead to inclusion of restrictions on burning in the TAC agreements (the public policy portion of the zero-deforestation agreements), which already require legal compliance with other social and environmental policies.

Along with any expanded restrictions on burning, the personnel and financial resources necessary for effective enforcement would need to be allotted to responsible agencies like Ibama, as well as to Embrapa, state extension agencies, and to rural credit programs to ensure that effective alternatives to burning for land management are widely available to ranchers and other Amazon land users (Pereira et al., 2020; Pivello et al., 2021). Indeed, smallholders practicing swidden agriculture are particularly vulnerable to both the negative consequences of fires and to the negative consequences of restrictions on fires (Carmenta et al., 2019). Thus, the reduction of barriers to alternative practices, including improvements to the availability of rural financing and increases in access to appropriate technologies for local conditions, as well as the expansion of resources for controlling fires available to farmers, would simultaneously benefit land users and improve environmental outcomes (Cammelli et al., 2020).

\section{CONCLUSION}

In spite of a moratorium on burning that covered the most critical months, the 2020 fire season was one of the worst of the last decade. Fires disproportionately occurred on cattle properties, including those that supply major slaughterhouses in the region. Identifying suppliers that contributed to these fires should be a priority for Brazil's cattle sector as it continues to increase its foothold in international markets (Globo, 2021) and improve its reputation regarding environmental issues. 


\section{AUTHOR CONTRIBUTIONS}

IS designed the study, conducted the analysis, and produced the figures. IS, LR, and HG contributed to assembling the datasets and writing the manuscript. All authors contributed to the article and approved the submitted version.

\section{REFERENCES}

Alix-Garcia, J., and Gibbs, H. K. (2017). Forest conservation effects of Brazil's zero deforestation cattle agreements undermined by leakage. Glob. Environ. Change 47, 201-217. doi: 10.1016/j.gloenvcha.2017.08.009

Aragão, L. E., Anderson, L. O., Fonseca, M. G., Rosan, T. M., Vedovato, L. B., Wagner, F. H., et al. (2018). 21st Century drought-related fires counteract the decline of Amazon deforestation carbon emissions. Nat. Commun. 9:536. doi: 10.1038/s41467-017-02771-y

Araujo, C., Bonjean, C. A., Combes, J. L., Motel, P. C., and Reis, E. J. (2009). Property rights and deforestation in the Brazilian Amazon. Ecol. Econ. 68, 2461-2468. doi: 10.1016/j.ecolecon.2008.12.015

Barlow, J., Lennox, G. D., Ferreira, J., Berenguer, E., Lees, A. C., Mac Nally, R., et al. (2016). Anthropogenic disturbance in tropical forests can double biodiversity loss from deforestation. Nature 535, 144-147. doi: 10.1038/nature18326

Börner, J., Marinho, E., and Wunder, S. (2015). Mixing carrots and sticks to conserve forests in the Brazilian Amazon: a spatial probabilistic modeling approach. PLoS One 10:e0116846. doi: 10.1371/journal.pone.0116846

Brazil (2020). Decree Suspending the Issuing of Burning Permits During 120 Days from 15 July 2020. Available online at: http://www.planalto.gov.br/ccivil_03/ _ato2019-2022/2020/decreto/D10424impressao.htm (accessed September 21, 2021).

Cammelli, F. (2013). Smallholders Collective Action and Fire Risk in the Brazilian Amazon. Ph.D. thesis. Florence: University of Florence.

Cammelli, F., Garret, R. D., Barlow, J., and Parry, L. (2020). Fire risk perpetuates poverty and fire use among Amazonian smallholders. Glob. Environ. Change 63:102096.

Cano-Crespo, A., Oliveira, P. J., Boit, A., Cardoso, M., and Thonicke, K. (2015). Forest edge burning in the Brazilian Amazon promoted by escaping fires from managed pastures. J. Geophys. Res. Biogeosci. 120, 2095-2107. doi: 10.1002/ 2015JG002914

Carmenta, R. (2013). From Earth Observation to Ethnography: Examining Smallholder Fire Management in the Brazilian Amazon. Ph.D. thesis. Bailrigg: Lancaster University.

Carmenta, R., Coudel, E., and Steward, A. M. (2019). Forbidden fire: Does criminalising fire hinder conservation efforts in Swidden landscapes of the Brazilian Amazon? Geograph. J. 185, 23-37. doi: 10.1111/geoj.1 2255

Carmenta, R., Vermeylen, S., Parry, L., and Barlow, J. (2013). Shifting cultivation and fire policy: insights from the Brazilian Amazon. Hum. Ecol. 41, 603-614. doi: 10.1007/s10745-013-9600-1

Chain Reaction Research (2020). Deforestation for Agricultural Commodities a Driver of Fires in Brazil, Indonesia in 2019. Available online at: https: //chainreactionresearch.com/wp-content/uploads/2020/05/Deforestationdriven20fires.pdf (accessed July 28, 2021).

CNN (2020). Tens of Thousands of Fires are Pushing the Amazon to a Tipping Point. Available online at: https://www.cnn.com/2020/09/10/americas/brazilamazon-fires-carlos-nobre-intl/index.html (accessed March 3, 2021).

Fraser, J. A., Alves-Pereira, A., Junqueira, A. B., Peroni, N., and Clement, C. R. (2012). Convergent adaptations: bitter manioc cultivation systems in fertile anthropogenic dark earths and floodplain soils in Central Amazonia. PLoS One 7:e43636. doi: 10.1371/journal.pone.0043636

Gibbs, H. K., Munger, J., L’Roe, J., Barreto, P., Pereira, R., Christie, M., et al. (2016). Did ranchers and slaughterhouses respond to zero-deforestation agreements in the Brazilian Amazon? Conserv. Lett. 9, 32-42. doi: 10.1111/conl.12175

Global Canopy (2021). Smoking Out the Fire Risk In Beef Supply Chains. Available online at: https://globalcanopy.org/insights/insight/smoking-outthe-fire-risk-in-beef-supply-chains/ (accessed October 7, 2021).

\section{FUNDING}

This research was funded by the Gordon and Betty Moore Foundation (Grant No. 1810027) and Norwegian Agency for Development Cooperation's Department for Civil Society under the Norwegian Forest and Climate Initiative (Grant No. 706055).

Global Fire Emissions Database [GFED] (2020). Amazon Dashboard. Available online at: https://globalfiredata.org/pages/amazon-dashboard/ (accessed December 1, 2020).

Global Witness (2020). Beef, Banks and the Brazilian Amazon. Available online at: https://www.globalwitness.org/en/campaigns/forests/beef-banks-andbrazilian-amazon/ (accessed July 28, 2021).

Globo (2021). Exportação Brasileira de Carne Bovina volta a Subir em Agosto. Available online at: https://g1.globo.com/economia/agronegocios/noticia/ 2021/09/08/exportacao-brasileira-de-carne-bovina-volta-a-subir-em-agosto. ghtml (accessed October 7, 2021).

Greenpeace (2020). Fires are Raging in the Amazon-Again. Available online at: https://www.greenpeace.org/international/story/44159/fires-brazil-bolsonaroamazon-deforestation-2020/ (accessed March 3, 2021).

IBGE (2017). Instituto Brasileiro de Geografia e Estatística Agricultural Census. Available online at: https://sidra.ibge.gov.br/tabela/6960 (accessed September 29, 2021).

INCRA (2020). Instituto Nacional de Colonizaçãoe Reforma Agrária, Assentamentos Rurais. Available online at: http://acervofundiario.incra.gov.br (Accessed June 18, 2020).

MapBiomas Project (2020). Collection $v 5.0$ of the Annual Land Use Land Cover Maps of Brazil. Available online at: https://mapbiomas.org/en/colecoesmapbiomas-1?cama_set_language=en (accessed July 28, 2020).

Mighty Earth (2019). The Companies Behind the Burning of the Amazon. Available online at: https://stories.mightyearth.org/amazonfires/index.html (accessed October 1, 2021).

Mongabay (2017). Cattle Industry Lags Behind in Addressing Impact on Deforestation. Available online at: https://news.mongabay.com/2017/03/cattleindustry-lags-behind-in-addressing-impact-on-deforestation/ (accessed September 20, 2021).

Mongabay (2020). Satellites, Maps and the Flow of Cattle: Brazilian Solutions for Reducing Deforestation are Already in Use. Available online at: https://news.mongabay.com/2020/11/satellites-maps-and-the-flow-of-cattlebrazilian-solutions-for-reducing-deforestation-are-already-in-use/ (accessed September 20, 2021).

OECO (2019). TAC da Carne no Pará: MPF diz que Ninguém está livre do Desmatamento. Available online at: https://www.oeco.org.br/reportagens/ tac-da-carne-no-para-mpf-diz-que-ninguem-esta-livre-do-desmatamento/ (accessed July 28, 2021).

Peña-Venegas, C. P., Verschoor, G., Stomph, T. J., and Struik, P. C. (2017). Challenging current knowledge on Amazonian dark earths: indigenous manioc cultivation on different soils of the Colombian Amazon. Cult. Agric. Food Environ. 39, 127-137. doi: 10.1111/cuag.12087

Pereira, R., Rausch, L. L., Carrara, A., and Gibbs, H. K. (2020). Extensive production practices and incomplete implementation hinder Brazil's zero-deforestation cattle agreements in Para. Trop. Conserv. Sci. 13:1940082920942014. doi: 10.1177/1940082920942014

Pivello, V. R., Vieira, I., Christianini, A. V., Ribeiro, D. B., da Silva Menezes, L., Berlinck, C. N., et al. (2021). Understanding Brazil's catastrophic fires: causes, consequences and policy needed to prevent future tragedies. Perspect. Ecol. Conserv. 19, 233-255. doi: 10.1016/j.pecon.2021. 06.005

Reydon, B. P., Fernandes, V. B., and Telles, T. S. (2020). Land governance as a precondition for decreasing deforestation in the Brazilian Amazon. Land Use Policy 94, 104313. doi: 10.1016/j.landusepol.2019.104313

Setzer, A. W., Sismanoglu, R. A., and Martins, G. (2016). Metodologia do Cálculo do Risco de Fogo do Programa Queimadas do Inpe-Versão 10, Junho/2016. Available online at: https:/queimadas.dgi.inpe.br/ rqueimadas/documentos/ RiscoFogo_Sucinto_20171121.pdf (accessed September 20, 2021). 
SiCAR (2020). Cadastro Ambiental Rural. Available online at: https://www.car.gov. br/publico/imoveis/index (accessed December 8, 2020).

Skidmore, M., Moffette, F., Rausch, L. L., and Gibbs, H. K. (2020). Characterizing Compliance in Cattle Supply Chains: What Factors Encourage DeforestationFREE PRODUCTIOn in the Brazilian Amazon? Report for the Meridian Institute - Supply Chain Sustainability Research Fund. Available online at: https://743a3c3a-9890-45b8-a645-7c0b50c92edb.filesusr.com/ugd/5ela0d_ d0736c11c9c949c39c802c6f9da0d1a5.pdf (accessed May 15, 2021).

Terra Legal (2015). Land Titling Program. Available online at: https: //acervofundiario.incra.gov.br/i3geo/interface/openlayers.htm (accessed November 2, 2015).

TerraBrasilis (2020). PRODES and DETER Land Cover and Deforestation Alerts. Available online at: http://terrabrasilis.dpi.inpe.br/downloads/ (accessed November 28, 2020).

The Guardian (2020). Brazil's Amazon rainforest suffers worst fires in a decade. Available online at: https://www.theguardian.com/environment/2020/ oct/01/brazil-amazon-rainforest-worst-fires-in-decade (accessed March 3, 2021).

Walker, N. F., Patel, S. A., and Kalif, K. A. (2013). From Amazon pasture to the high street: deforestation and the Brazilian cattle product supply chain. Trop. Conserv. Sci. 6, 446-467. doi: 10.1177/194008291300600309
Zu Ermgassen, E. K., Godar, J., Lathuillière, M. J., Löfgren, P., Gardner, T., Vasconcelos, A., et al. (2020). The origin, supply chain, and deforestation risk of Brazil's beef exports. Proc. Natl. Acad. Sci. U.S.A. 117, 31770-31779. doi: 10.1073/pnas.2003270117

Conflict of Interest: The authors declare that the research was conducted in the absence of any commercial or financial relationships that could be construed as a potential conflict of interest.

Publisher's Note: All claims expressed in this article are solely those of the authors and do not necessarily represent those of their affiliated organizations, or those of the publisher, the editors and the reviewers. Any product that may be evaluated in this article, or claim that may be made by its manufacturer, is not guaranteed or endorsed by the publisher.

Copyright (c) 2021 Schelly, Rausch and Gibbs. This is an open-access article distributed under the terms of the Creative Commons Attribution License (CC BY). The use, distribution or reproduction in other forums is permitted, provided the original author(s) and the copyright owner(s) are credited and that the original publication in this journal is cited, in accordance with accepted academic practice. No use, distribution or reproduction is permitted which does not comply with these terms. 